\title{
Capability approach on pedagogical use of ICT in schools
}

\author{
A CHIGONA AND W CHIGONA *
}

\begin{abstract}
The use of Information Communication Technologies (ICTs) for enhancing pedagogical activities has enormous potential to raise standards and increase educators' and learners' capabilities. However, research and anecdotal evidence in South Africa show that there is a low adoption rate of ICT among educators in schools and, in cases where the technology has been adopted, the impact has not been optimal. This qualitative study analyses the factors which prevent educators from using ICTs in their pedagogy. The perspectives of limited access and/or use of ICT as deprivation of capabilities provide a conceptual base for this paper. Sen's Capability Approach has been used as a conceptual lens to examine the educators' situation regarding integration of the technology in their pedagogy. Face-to-face interviews, with fourteen educators and two Khanya personnel, were used to gather data for the study. The findings show that personal, social and environmental factors are hindering the educators from realising their potential capabilities from the ICTs available in their schools. For effective use of the technology in the classrooms, the educators need to be equipped with Technological Pedagogical Content Knowledge.
\end{abstract}

Keywords: educator, Capability Approach, technology, conversion factors, pedagogy.

Disciplines: Pedagogy, Information Communications Technology

\section{Introduction}

Over the last decade there has been a concerted effort to promote the use of Information Communication Technologies (ICTs) in schools in developing countries. The integration of ICT in classrooms has an impact on learning; however, this is only realisable where educators are able to appreciate that the effective use of the technology requires new capabilities and approaches to pedagogy. While educators' beliefs and values are important in shaping technology-mediated teaching and learning, these might not suffice to enable the educators to appropriate the technologies appropriately in their curriculum delivery (Glover \& Miller, 2001; Cox et al 2003). What may be required most is extensive knowledge of ICT, coupled with skills on how to integrate the technology in pedagogy.

Agnes and Wallace Chigona are attached to the Department of Information Systems, University of Cape Town, Private Bag, Rondebosch 7701 South Africa. Thei respective emails are: agnes.chigona@uct.ac.za and wallace.chigona@uct.ac.za. 
Educators' pedagogical practices when using ICT may be affected by a number of factors. The educators could be affected by their knowledge about their own curriculum, as well as their capabilities to integrate ICTs into the curriculum. Moseley et al (1999) posit that there is a clear distinction between educators who choose ICT resources to fit within a particular topic and those who choose resources merely to deliver curriculum, without any direct application to the curriculum components. Furthermore, Moseley et al (1999) argue that when educators use their knowledge of the subject and along with their knowledge of how learners understand the subject, as well as their pedagogical knowledge on integrating the technology into the curriculum delivery, their use of ICT has the benefit of enhancing teaching and learning. This means pedagogical uses of technology require the development of a complex, situated form of knowledge, namely Technological-Pedagogical-Content-Knowledge (TPCK) (Mishra and Koehler, 2006: 1017). Effective teaching using ICT requires an understanding of how the technology relates to the pedagogy and content; hence the knowledge about technology cannot be dealt with as context-free (Neiss, 2005; Hughes, 2005; Mishra and Koehler, 2006). Therefore there is a need for an inter-disciplinary approach to studies on the use of ICTs in education.

Besides the complex, situated form of knowledge discussed above, there are other factors that prevent educators from using ICTs in their pedagogy (Cox et al, 2003; Grainger and Tolhurst, 2005). These factors include individual capabilities to use ICTs, access to resources, ease of use, incentives to change, support and collegiality in their school, school policies, commitment to professional learning and background in formal ICT training (Mumtaz, 2000; Becta, 2003). The educators' capabilities and constraints determine their efficacy to use the technology in their classrooms.

In this paper, we examine the educators' capabilities and constraints on pedagogical use of ICTs in schools in disadvantaged areas. This context is interesting because the schools in disadvantaged communities are beset with a myriad of challenges resulting from inadequate resources. It is generally hoped that ICT would be useful in such situations to supplement the meagre resources (Hardman, 2005). We employed a Capability Approach to understand factors which may hinder educators, in a disadvantaged schools context, from effectively using ICT for curriculum delivery. In particular, we employed the Capability Approach developed by Amartya Sen who argues that social arrangements should aim to broaden individuals' capabilities - their freedom to achieve valuable beings and actions. Sen believes that focusing on freedom is a more accurate way to develop what individuals really value (Sen, 1999). Sen, therefore, discourages focusing on the availability of resources, but recommends that the focus be on how the resources can translate into meaningful benefits for individuals. Based on the recommendations of Zheng and Walsham (2008), the Capability Approach looks at the failure to derive meaningful benefits from ICT as a deprivation of the educators' freedoms and therefore in need of being addressed. Based on the Capability Approach, this empirical study asks the following questions:

- What pedagogical ICT benefits and/or well-beings do educators perceive from ICTs?

- What factors impact on the pedagogical utilisation of ICT in the schools?

This study uses the Khanya project (in the Western Cape Province, South Africa) as a case study. In South Africa, there have been a number of initiatives to make the technologies available in schools and to equip educators with ICT skills to be used in the curriculum delivery. The Khanya project, a Western Cape Department of Education initiative, is one of these initiatives. The project, which started in 2001, has been equipping schools in the Western Cape Province with information, communication and audiovisual technology to improve teaching and learning, 
or curriculum delivery. According to the project, "by the start of the 2012 academic year, every educator in every school of the province will be empowered to use appropriate and available technology to deliver curriculum to each and every learner in the province" (Khanya, 2008). According to the 2008 Khanya report, $59 \%$ of schools in the province had "at least one computer facility", $70 \%$ of educators were trained and $71 \%$ of learners had access to ICT in their schools (Khanya, 2008). Anecdotal evidence as well as research conducted in Khanya project schools (Miller, Naidoo, and Van Belle, 2006) show that not all ICT-trained educators are using the technology in their teaching. Using Sen's Capability Approach, we analysed empirical data which we collected through interviews with educators in Khanya schools, as well as Khanya personnel who are managing the project.

Research on ICTs in education in developing countries has focused mainly on physical access to resources, infrastructure, support and collegiality in schools, policies and basic training of the teachers on how to use the technologies. There is a tendency to look at the ICTs and how they are used in the schools and not at the capabilities which both educators and learners have to effectively use the technologies. We argue that merely introducing the ICTs in the schools is not adequate to guarantee the effective integration of the technologies in pedagogy. Hence this study focuses on the educators' capabilities when using the technology in their pedagogy. The study makes a practical contribution in that it seeks to contribute towards improving the utilisation of ICTs for curriculum delivery in developing countries. Even though the study uses a single case study of the Khanya project, it is hoped that the findings will be relevant to other similar projects in South Africa as well as in other developing countries. Further, the use of a framework that allows us to look beyond the technological aspects of school ICT projects, allows us to place the debate in an interdisciplinary research domain.

\section{ICT and Pedagogy}

ICT holds much promise for use in teaching and learning. Literature shows that technology can effectively improve pedagogical abilities, hence increasing learners' performances (Louw, Muller and Tredoux, 2008). In spite of teachers often being constrained by the ICT resources available to them, there are examples in the literature of educators appreciating the technology when it is integrated in pedagogy. Cox, Preston and Cox (1999) show that many educators perceive ICT as a tool for improving the presentation of material, for making lessons more fun for the learners and for making administration more efficient. In addition, ICT provides fast and accurate feedback to learners (Becta, 2003).

The use of ICTs in pedagogy could promote 'deep' learning and allow educators to respond better to the different needs of different learners (Lau and Sim, 2008). ICT has the means to aid in the preparation of learners by developing cognitive skills, critical thinking skills, information access, evaluation and synthesising skills (Cawthera, 2000; Castro, 2003). Hardman (2005:100) argues that "placing this new technology in schools could help alleviate the deepening crisis, enabling shifts in pedagogical practices and thus potentially benefiting students' learning."

It is believed that ICT-supported learning environments could be beneficial to a constructivist teaching approach (Newhouse, 2002). One of the most important components of the constructivism theory of learning is the concept of proximal learning, which accepts that a learner constructs his/her own knowledge for which scaffolding is initially required. The scaffolding could be provided by a tutor or computer. Thus, the technology can be used to help 
create the types of learning environments and the types of support for learning that are known to be ideal; these are argued to have been ignored or have failed to be widely implemented in the past (Newhouse, 2002:10).

While ICTs may be used to either maintain a learning environment or be used to support the learner in the constructivist classroom, it is advocated that a blend of instruction and construction is employed. For instance, DeCorte (1990) posits that there is a need for balancing the approaches when using the ICT in schools:

\section{A powerful computer learning environment is characterised by a good balance between discovery learning and personal exploration on one hand, and systematic instruction and guidance on the other, always taking into account the individual differences, inabilities, needs and motivation between students (DeCorte, 1990:74).}

This suggests that the use of ICT for teaching and learning should be understood within a broader framework of educational practice. Thus, understanding of the ideal use of the technology in pedagogy requires examining teachers' ideas, values, beliefs, thinking and environments that lead to observable elements in the practice (Cox et al, 2003).

The educators' own pedagogical beliefs and values play an important part in shaping technologymediated learning opportunities. However, the educators may need extensive knowledge of ICT to be able to select the most appropriate resources, and to understand how to effectively integrate the technology into their pedagogies (Cox et al, 2003). The use of ICT and integration of technology into the educators' pedagogy is dependent on a number of factors. Such factors include teachers' readiness, confidence, knowledge and ability to evaluate the role of ICT in teaching and learning, and lack of skills to be able to use the ICT equipment (Manson, 2000; Lau and Sim, 2008). According to Manson (2000) other factors include school leadership, curriculum planning, technical support, the actual use of ICT, training and personal development, the school council, the budget and the learning technologies committee.

Slaouti and Barton (2007) have also shown that hurdles such as access to equipment, time pressures, lack of mentors and opportunities for apprenticeship have an impact on educators' ability to integrate ICT in their pedagogy. Cox et al (1999) argue that some educators do not use ICT in their teaching because they (the educators) are computer-phobic. It is also reported that sustained and regular use of ICT to have any benefit on the teaching and learning in some classrooms rarely occurs because of the limited number of ICT resources in schools (Comber $e t$ al, 2002).

\section{Theoretical framework: Capability Approach}

Limited access or use of ICT as deprivation of capabilities provides a conceptual basis for this paper. Consequently, we employed a Capability Approach as a conceptual lens to examine the educators' situation regarding ICT for pedagogical use. The Capability Approach has been developed, refined and defended over a period of time by Sen in different articles (Sen, 1984; $1985 ; 1987 ; 1992 ; 1993 ; 1999 ; 2000)$. The approach is directly concerned with what people are effectively able to do and to be, taking into account the resources to which they have access. In other words, the approach focuses on individuals' capabilities and freedom. Sen (1999) defines the term 'freedom' as effective opportunities individuals have to live the sort of lifestyle they have reasons to value. According to Sen (1993), in social evaluations and policy designs, the concern 
should be on individuals' capabilities, on the quality of their lives and on freeing their lives from obstacles.

The Capability Approach to a person's advantage is concerned with evaluating it in terms of his or her actual ability to achieve various valuable functionings as a part of living. The corresponding approach to social advantage - for aggregative appraisal as well as for the choice of institutions and policy - takes the set of individual capabilities as constituting an indispensable and central part of the relevant informational base of such evaluations (Sen, 1993:30).

Using the Capability Approach, Zheng and Walsham (2008) argue that people should look at poverty not only as lowness of income but also as 'impoverished lives', i.e. the deprivation of the freedom to be involved in important activities that one might wish to choose. Thus the Capability Approach centres not on the income level per se but rather on the capabilities which individuals may fail to enjoy due to low income levels, e.g. access to education, participation in economic life and autonomy in decision-making. According to Sen, human development should be perceived as a process of expanding individuals' capabilities. The approach explicitly takes into account environmental conditions, social pressures and conversions which are some of the basic concepts that we are using, since the study has been designed to mainly use the basic concepts of the Capability Approach as a sensitising tool.

The approach seeks to understand transformation of commodities into valuable beings and doings, i.e. vectors of functioning or capability sets. From the vectors of functioning, individuals choose capabilities or functioning which they would like to achieve. The choice of specific subsets of functionings creates a given level of well-being.

\section{Functionings and capabilities}

Functionings and capabilities are the central concepts of the Capability Approach. The term functionings "reflects the various things a person may value doing or being" (Sen, 1999: 75), i.e. valuable states that lead an individual to well-being (e.g. being safe, having an educated mind, having a good job). Functions are related to commodities but they describe an individual's beings and doings. On the other hand, capabilities refer to "the alternative combinations of functionings that are feasible for her to achieve. Capability is thus a kind of freedom - the substantive freedom to achieve alternative functionings combinations (...the freedom to achieve various lifestyles)" (Sen, 1999:75). That is, capabilities describe the actual opportunities open to an individual. The two terms are interrelated but have different meanings:

\section{Functioning is an achievement, whereas a capability is the ability to achieve. Functionings are, in a sense, more directly related to living conditions, since they are different aspects of living conditions. Capabilities, in contrast, are notions of freedom in the positive sense: what real opportunities you have regarding the life you may lead (Sen, 1987:36).}

Sen does not propose or endorse a fixed list of capabilities; instead he argues that the choice and importance of capabilities depend on personal value discretion which could be influenced by the nature and purpose of the exercise. The flexibility of the framework permits researchers to develop and apply it in different ways (Alkire, 2002:8-11). 


\section{Well-being and agency}

Well-being is an evaluation of anything in an individual's situation, i.e. an evaluation which is focused on the individual's being (Gasper, 2002). However, for Sen, 'well-being' refers only to one's own gratification and is distinct from the pursuit and fulfilment of one's ideals and commitments. On the other hand, agency is an individual's ability to pursue and realise what he/she values and has reason to value, or, in other words, the freedom to set and pursue one's own goals and interests (Sen, 1985). Well-being may be one of the goals and interests the individual is pursuing. The individual is viewed as an agent thus "someone who acts and brings about change" (Sen, 1999:19). He/she is viewed as an agent and not as a patient whose wellbeing (or its absence) is the only concern (Robeyns, 2005). Consequently, the Capability Approach is not solely concerned with the possession of material resources (albeit these could be essential to achieve goals and interests), but rather a person's real opportunity in achieving his/her well-being and freedom and agency freedom. The two freedoms are interrelated in that the deprivation of one often has the causal impact on the other (Zheng and Walsham, 2008).

\section{Commodities, freedom and capabilities}

In this study, we needed to understand the relationship between commodities (resources), functionings and capabilities. The commodities in this study are the computers in the Khanya laboratories the functionings are the uses educators make of the commodities at their command, and capabilities are freedoms and/or the real actual possibilities open to the teachers who were given the Khanya laboratories in their schools. However, the extent to which individuals can generate capabilities from commodities is influenced by conversional factors. Conversion factors can be categorised into:

- $\quad$ personal characteristics, e.g. mental and physical condition, literacy and gender

- $\quad$ social setting characteristics, e.g. social norms (like rule of behaviour, materialism, etc), social institutions (like political rights, public policies, etc), and power structures (like hierarchy, politics) and

- environmental factors, e.g. climate, infrastructure, resources and public goods (Sen, 1992).

According to Zheng and Walsham (2008), achievement of functionings (from the set of available capabilities) is a result of the individual's choice to select from the capabilities available, subject to individual's preferences, social pressure and other decision-making mechanisms. These are again affected by personal, social and environmental factors.

\section{Limited use of technology as a capability deprivation}

Research shows that there is limited use of ICT by teachers in their pedagogy. Bingimlas (2009: 237) postulates that "the act of integrating ICT into teaching and learning is a complex process and one that may encounter a number of...barriers" which could lead to deprivation of the educators' capabilities. This study focuses on the limited access and use of ICT by educators in schools in disadvantaged areas. The perspective of limited access or use of ICT 
as deprivation of capabilities provides a conceptual basis for this paper. Taking this approach, we explored the integration of ICTs in pedagogy by teachers through the following questions:

- Which capabilities do educators value in the use of ICT in their pedagogy?

- Who may be disadvantaged by the deprivation of these capabilities?

- How do personal, social and environmental factors affect the realisation of capabilities and functionings from the use of ICTs?

In this case, the Capability Approach provides a set of concepts to unpack the relationship between ICT and its limited use in the educators' pedagogy as capability deprivation. This is elaborated in Table 1.

\begin{tabular}{|c|c|}
\hline Commodity/resource & $\begin{array}{l}\text { The type of technology } \\
\text { The characteristics of technology relevant to pedagogy }\end{array}$ \\
\hline Conversion factors & $\begin{array}{l}\text { Personal factors, e.g. training } \\
\text { Social factors, e.g. social institutions, social norms, politics } \\
\text { Environmental factors, e.g. infrastructure, resources }\end{array}$ \\
\hline Agents & Whose capabilities are deprived, e.g. educators, learners \\
\hline Capabilities & $\begin{array}{l}\text { The capabilities the learners and educators are deprived of } \\
\text { Well-being freedom, e.g. education, utilisation of technology etc. } \\
\text { Agency freedom, e.g. taking advantage of available resources, policy } \\
\text { making }\end{array}$ \\
\hline
\end{tabular}

Table 1: Concepts for unpacking ICT and its limited use as capability deprivation (Zheng and Walsham, 2008)

The perspective of limited access and use of ICT as capability deprivation will be used to illustrate two aspects of the phenomenon. Firstly, limited access and use in schools could be due to physical unavailability of the technology in the schools. Secondly, limited access and use of ICT may be due to relational factors and results from types of capability failure other than the deprivation of the usage of the technology.

\section{Concepts used in the study}

An educator may be able to use a Khanya laboratory (commodity) at school to deliver curriculum using the technology (functioning). If, however, the educator is unable to use the Khanya laboratory (e.g. due to lack of skills), then the availability of the commodity at the school would not result in the functioning i.e. using ICT for teaching. However, the access to the technology coupled with the educator's personal characteristics (ICT training etc), creates the capability for the educator to incorporate ICT in his/her teaching whenever necessary. Furthermore, let us suppose that the educator values this capability for making teaching and learning interesting thus having this capability contributes to both the educator's and learners' happiness (selffulfilment) or well-being. 


\section{Research Methodology}

This study was done qualitatively using an interpretive approach. We were interested in exploring factors which may lead to educators' deprivation from effectively using ICT in their pedagogies. Therefore, we collected and analysed empirical data using the qualitative research approach. Qualitative research is defined as "the use of qualitative data such as interviews, documents and participant observation data to understand and explain social phenomena" (Myers, 1997). According to Myers, qualitative research methods are designed to help researchers understand people and the social and cultural contexts within which they live. In addition, the qualitative approach is eminently effective in determining the deeper meaning of experiences of human beings and in giving a rich description of the specific phenomena being investigated in reality (Rubin and Babbie, 1989). Hardman (2005:102) also notes that "interviews can be useful tools for unpacking motives and experiences". We used semi-structured interviews to explore the deeper meaning of experiences that educators in Khanya Schools place on their use of ICT for curriculum delivery.

\section{Research sample}

Interview respondents for the study were drawn from four randomly sampled high schools in the disadvantaged areas of the Western Cape. The schools were sampled from those that are under the Khanya project. Fourteen educators from the randomly sampled schools were interviewed about the utilisation of computer laboratories and the factors which may contribute to capability deprivation of educators in their schools. At least three of the interview respondents from each school were educators of the subjects which Khanya recognises as the focus of the schools (i.e. Mathematics and English). A representative of Khanya management and one person working for a Khanya Private Partnership were also included in the study in order to understand their expectations on the educators' use of ICT.

\section{Data gathering and analysis}

We conducted in-depth interviews with all the participants. All the interviews were audiorecorded and then transcribed. The transcription process helped us get closer to the data - we were able to think about what the interviewee was saying and how this was said. We read each typed transcript several times while listening to the corresponding audio tape to ensure accuracy of the transcription and to come to a better overall understanding of each participant's experience. The process of transcribing and listening also prompted additional questions for subsequent sets of interviews.

Afterwards we did a detailed systematic qualitative analysis, case by case. We read and examined each transcript multiple times, each time annotating the text with initial comments pertaining to conversion factors and capabilities affected. After this we extracted and listed themes. The themes were then clustered in a meaningful way by looking for connections between them to develop super-ordinate themes. 


\section{Results}

It was noted that most educators were aware of the benefits ICTs would offer towards teaching and learning. However, the integration of ICTs in the curriculum delivery was generally low. The analysis revealed a number of conversion factors that led to insufficient or no integration of ICT in the Khanya schools, hence leading to the capability deprivation of educators to effectively deliver curriculum and for learners to receive quality education using the technology. The factors can be grouped into personal, social and environmental factors. Table 2 summarises the capabilities and conversion factors. The conversion factors are discussed in the ensuing subsections.

\begin{tabular}{|c|c|c|c|c|}
\hline \multirow[t]{2}{*}{ Commodity } & \multirow[t]{2}{*}{ Agents } & \multirow[t]{2}{*}{ Conversion factors } & \multicolumn{2}{|c|}{ Capabilities deprivation } \\
\hline & & & $\begin{array}{l}\text { Well-being } \\
\text { freedom }\end{array}$ & Agency freedom \\
\hline \multirow[t]{8}{*}{ Khanya lab } & \multirow[t]{7}{*}{ Educators } & $\begin{array}{l}\text { Personal factors: } \\
\text {-Technological (ICT) skills }\end{array}$ & To be able to use & \\
\hline & & -Technological Pedagogical & ICT & \\
\hline & & Content Knowledge & $\begin{array}{l}\text { To integrate ICT in } \\
\text { pedagogy }\end{array}$ & \\
\hline & & $\begin{array}{l}\text { Social factors: } \\
\text {-Policy on the use of } \\
\text { computer lab }\end{array}$ & $\begin{array}{l}\text { To teach using ICT } \\
\text { without barriers }\end{array}$ & $\begin{array}{l}\text { To be engaged in the } \\
\text { policy-making of the } \\
\text { computer lab }\end{array}$ \\
\hline & & $\begin{array}{l}\text {-Freedom to access computer } \\
\text { lab }\end{array}$ & & $\begin{array}{l}\text { To take advantage of } \\
\text { computer technology }\end{array}$ \\
\hline & & $\begin{array}{l}\text { Environmental factors: } \\
\text {-Adequate equipment }\end{array}$ & $\begin{array}{l}\text { To have support } \\
\text { with regards to ICT }\end{array}$ & $\begin{array}{l}\text { To effectively deliver } \\
\text { curriculum using }\end{array}$ \\
\hline & & $\begin{array}{l}\text {-Technical support for } \\
\text { using the technology }\end{array}$ & in all subjects & $\begin{array}{l}\text { technology available at } \\
\text { school }\end{array}$ \\
\hline & Learners & $\begin{array}{l}\text { Environmental factor } \\
\text {-Conducive learning } \\
\text { environment }\end{array}$ & $\begin{array}{l}\text { To receive quality } \\
\text { education }\end{array}$ & \\
\hline
\end{tabular}

Table 2: $\quad$ A summary of conversion factors and capabilities

\section{Personalfactors}

Under the personal conversion factors, we identified two factors, namely technological knowledge/skills and Technological Pedagogical Content Knowledge.

\section{Technological skills}

While the teachers require technological knowledge to be able to operate the technologies, our analysis shows that low levels of ICT literacy amongst the educators was one of the factors that contributed to their limited use of the technology. Thus, though the schools had the technology which could have been an important commodity for teaching and learning, very few educators were incorporating the technology in their pedagogy. The Khanya project trains educators in the schools which are part of the project on how to use the ICTs. However, it appears that the training was not always effective since many educators were still not skilled or confident enough to use the technology. One educator indicated that although they received the Khanya training: 


\section{I still don't know much about computers. I need more training so I can use the computers in my class.}

Some respondents noted that the challenge was that the project offered training at the start of the project at the respective schools; however, there was no follow-up training. Further, since the training, some teachers had moved from the school and the school had received new teachers with no ICT skills. There was an expectation that the teachers who received the training would train the new teachers; however, this was not happening.

This finding is in line with Lau and Sim (2008:20) who show that, "despite the apparent benefits of the use of ICT for educational purposes...the learning potential of ICT is deprived as many teachers are still not fully ICT-literate and do not use it in their teaching." As Miller et al (2006) note, schools in privileged areas can afford to arrange extra ICT training for their teachers; in contrast schools in disadvantaged areas rely on the training provided by Khanya - unfortunately that was not adequate.

\section{Technological Pedagogical Content Knowledge}

Some teachers felt they were computer literate. They were able to use the computers for administration purposes, however they were not confident to use the technology for teaching. For instance, a Geography teacher said:

\section{I know I can use the computers to teach some topics in Geography but I don't know how exactly to do that.}

It may be argued that the technology provided the educators with a limited set of functionings due to inadequate ICT training, which resulted in low technological knowledge. The situation was exacerbated because the training they received from Khanya might have been technicallybiased (as claimed by the respondents) and failed to provide the educators with the skills on how to integrate the technology in their teaching, i.e. it did not equip the teachers with Technological-Pedagogical-Content-Knowledge. At a deeper level, the problem could be attributed to teacher-training programs; the design and implementation of the teacher training programs treat the technology as constituting a separate set of knowledge and skills that have to be learned. It seems the relationship between these skills and the tried and true basis of teaching (content and pedagogy) is non-existent or considered to be relatively trivial to acquire (Mishra and Koehler 2006). It is vital that the relationships between the three components be considered as a unit and not in isolation. This knowledge can enable the teachers to integrate the ICTs in their teaching.

\section{Social factors}

\section{Policy on the use of computer laboratory}

The rules set by the Khanya project on who could use the technology and what it could be used for affected the level of usage and the benefits derived from the technology. In some instances, depending on subjects (fields of study), educators could not access computer laboratories due to the rules. As reported by the respondent from a Khanya Private Partnership, the Khanya laboratory in schools is set up with a given focus, e.g. on Mathematics or on the English language. On this point one educator lamented that: 
They [Khanya] prescribe who can use it and who cannot use it and when it can be used and when it cannot be used and all these things. ... the rules attached to Khanya are too strict, there is no freedom whatsoever, if they say the Maths people can use it then only the Maths people can use it.

In addition, Khanya provided ICT facilitation only for the subjects which were the focus of the school. This arrangement disadvantaged the educators of other subjects in the institution as they were not provided with ICT support from Khanya. Since the schools were disadvantaged, the equipment provided by Khanya was the only equipment they had and the schools could not afford alternative arrangements for those excluded from the Khanya technology. Some respondents felt that the policies about the usage of the computer laboratories were unfairly imposed on the schools and on the educators who were not included in the drafting of the policies. The educators felt they were deprived of their capability to participate in the decisionmaking.

\section{Freedom to access computer lab}

From the analysis, we see that at one level the educators of the subjects which the respective schools focused on were included in the project, while the educators of other subjects were excluded from taking advantage of the available technology. At another level, however, all educators (including those of the subjects the schools focused on) in the schools might have been unfairly included in the Khanya laboratory because their agency freedom to participate in the decision-making for the ICT at their institution was restricted. This reflects what Sen (2000) posits:

\section{Exclusion from the process of governance and political participation is indeed an impoverishment of human lives, no matter what our per capita income may be.}

Further, since the laboratories could only be opened during the periods permitted by the Khanya policy, it resulted in some educators not having an opportunity to develop their skills on the technology for teaching, as reported by one educator:

The red tape around the use of the laboratories prevents the educators from having the opportunities to get into the laboratories the hours that they need to actually get familiar to the system...

The educators who were not allowed access to the Khanya laboratories were deprived of agency freedom to benefit from the available technology to utilise it in teaching. Similarly, the learners were deprived of the freedom to benefit from computer-supported education in the other subjects. In the case of educators, the restrictions may result in some lacking the opportunity to develop confidence and/or developing a fear of using the technology. Consequently, the educators may feel unfavourably included in the project because they have ICT at their school but do not have the freedom to use it whenever they need it. It may be argued, therefore, that the subject-focus restrictions may lead to some educators lacking freedom to benefit from the computer technology. This lack of freedom could be seen as a constitutive of, and contributor to, capability deprivation.

\section{Environmental factors}

Environmental factors such as inadequate computers, coupled with problems of technical support, negatively affected the use of the computers for teaching. 
Adequacy of equipment

It was also noted that the number of computers available at the schools was not sufficient for the schools needs; a number of learners shared a computer during lessons. One educator said:

On average our class sizes are $40+$ learners...the Khanya lab has a capacity to support 25 learners only. There are only 25 computers in the lab.

The Khanya personnel in the study agreed with the educator above, stating that the number of computers in the schools was one of the factors which limited technology teaching and learning. He said:

...if you got 2000 kids in a school and you have 25 or 30 computers, it is absolutely no good. You need far more or in fact you need technology in the classroom so that you can have an impact.

The problem was exacerbated by most of the computers often being non-functional. Since the learners had to share the computers, the educators experienced challenges in managing the teaching and learning environment. Educators noted that they spent a substantial amount of time getting the learners to settle down and to get logged onto the system. This affected the actual amount of time spent on the content.

Technical support

The analysis also shows that the educators who had the right to use computers did not have sufficient technical support regarding the use of the technology for teaching. The educators complained that the Khanya project technical support was not readily available and this was negatively affecting their use of the technology for teaching. One educator narrated that:

... if you have a hiccup here, you contact them, they will decide one day when they are going to come. They give you a little reference [number] just to keep you quiet and whether they are going to come today, tomorrow or next year doesn't matter...you just need to wait... the support isn't that great from their [Khanya's] side.

Because, in some cases, the support did not come in time, the educators' agency freedom to make effective use of ICT in their work was curtailed. Inadequate technical support, to an extent, discouraged some educators from planning to use the technology for their teaching. The educators did not want to get to the laboratory and face a technical fault which could not be rectified because there was no technical support at the school. The Khanya project designated a number of educators to perform trouble-shooting and provide support to colleagues. However, most of these teachers were not available to offer support because they "had their own classes to worry about". Due to lack of teachers (an endemic problem in schools in disadvantaged schools), the principals did not reduce their teaching-load to allow them time to perform the computersupport duties. Inadequate technical support indirectly contributed to reduced well-being on the part of the learners in terms of receiving high quality education.

\section{Conducive learning environment}

An insufficient number of computers, coupled with limited technical support, created an environment which was not conducive to effective technology-aided teaching and learning. Educators expressed frustrations because they faced challenges due to high learner-to-computer ratios when managing their classes. Teaching and learning is in such situations negatively affected. Literature also shows that in classrooms where learner-to-computer ratios are poor, educators have difficulties with classroom management (Becta, 2003). 


\section{Conclusions}

The use of ICTs in education offers hope to schools in disadvantaged communities. ICTs can be used to address a myriad of challenges bedevilling the schools in such communities. However, to achieve that dream, it is imperative that the ICTs should be integrated in teaching and learning. Previous studies and anecdotal evidence show that in many cases, with educators, that are not happening. It is imperative, therefore, to understand the challenges that affect the educators' capability and motivation to integrate ICTs in their pedagogy. Using the Khanya project as a case study, this study looked at the factors that may affect the integration of ICT in teaching and learning in the context of resource-deprived schools.

In this study we used Sens's Capability Approach as a conceptual framework to analyse ICT capability deprivation among educators in disadvantaged communities. Given the commodity which, in this case, is the computer laboratory, we analysed the conversion factors which could enable or hinder the educators from converting the commodity (technology) to capabilities. The analysis identified a number of conversion factors that include:

- insufficient technological skills and lack of technological pedagogical content knowledge

- $\quad$ policy on the use of the technology

- $\quad$ lack of freedom for some educators to access the laboratories

- $\quad$ inadequate technical support for the educators who are using the ICT for teaching and learning

- $\quad$ high learner-to-computer ratio, which results in an unconducive environment to learning

In order to improve the impact of ICTs in education and hence maximise the return on the ICT investment, there is a need for the school authorities and the funding agencies to mitigate these conversion factors. We appreciate that most of these factors would equally affect schools in affluent areas. However, we would argue that the factors are more prevalent in schools in disadvantaged communities, due to their lack of resources to organise their own training, their own support or the opportunity to acquire additional equipment. It may be argued that the most critical deprivation for resource-deprived schools is their dependency on external entities to manage their ICT resources. There is a need for education authorities and funding agencies to reconceptualise the provision and management of ICT resources in those schools. The challenge is that the schools cannot afford their own resources and will need an external entity to finance such resources. However, the resources should be provided in a way that empowers the schools.

\section{Acknowledgment}

An earlier version of the paper appears in the proceedings of the European Conference in Information Systems: Chigona, A. and Chigona W. (2010). An Investigation of Factors affecting the Use of ICT for Teaching in the Western Cape Schools. This paper has been substantially 
revised based on the discussion at the conference as well as the valuable comments from the reviewers for the journal.

\section{References}

Alkire S (2002). Valuing Freedom: Sen's Capability Approach and Poverty Reduction. Oxford University Press, Oxford

BECTA (2003). What the research says about using ICT in Maths. British Educational Communications and Technology Agency. Retrieved December 24, 2009 from http://partners.becta.org.uk/page documents/research/wtrs maths.pdf

Bingimlas KA (2009). Barriers to the successful integration of ICT in teaching and learning: A review of the literature. Eurasia Journal of Mathematics, Science and Technology Education, 5(3) 235-245

Castro C (2003). Education in the Information Age: Promises and Frustrations. Retrieved January 4, 2009, from http://www.iadb.org/sds/doc/Edu\&Tech2.pdf

Cawthera A (2003). Computers in secondary schools: high-cost problem or low-cost cure-all? Insights Education 1. Retrieved January 4, 2009, from http://www.id21.org/insights/insights-ed01/insights-issed01-art03.html

Comber C, Watling R, Lawson T, Cavendish S, McEune, R. and Paterson F. (2002), ImpaCT2: Learning at Home and School: case studies. Coventry: Becta/London: DfES

Cox MJ, Preston C and Cox K (1999). What Motivates Teachers to Use ICT? Paper presented at the British Educational Research Association Annual Conference, University of Sussex at Brighton, September 2-5

Cox M, Webb M, Abbott C, Blakeley B, Beauchamp T and Rhodes V (2003). ICT and pedagogy: A review of the research literature, ICT in Schools Research and Evaluation Series No. 18

DeCorte E (1990). Learning with new information technologies in schools: Perspectives from the psychology of learning and instruction. Journal of Computer Assisted Learning, 6, 69-87

Gasper D (2002). Is Sen's Capability Approach an Adequate Basis for Considering Human Development? Review of Political Economy, 14(4), 435-461

Grainger R and Tolhurst D (2005). Organisational Factors Affecting Teachers' Use and Perception of Information \& Communications Technology. In Proc. South East Asia Regional Computer Confederation (SEARCC) Conference 2005: ICT Building Bridges, Sydney, Australia. CRPIT, 46. Low, G., Ed. ACS. 13-22

Hardman J (2005). An exploratory case study of computer use in a primary school mathematics classroom: New technology, new pedagogy? Perspectives in Education, Vol. 23(4), 99111 
Hughes J (2005). The role of teacher knowledge and learning experiences in forming technologyintegrated pedagogy. Journal of Technology and Teacher Education, 13(2), 277-302

Khanya. (2008). Khanya Annual Report - for the period March 2007 - April 2008. Retrieved January 4, 2009, from www.khanya.co.za/projectinfo/docs/khanya annual rep 2008.pdf

Lau BT and Sim CH (2008). Exploring the extent of ICT adoption among secondary school teachers in Malaysia. International Journal of Computing and IT Research, Vol. 2 (2) $19-36$

Louw J, Muller J and Tredoux C (2008). Time-on-task, technology and mathematics achievement. Evaluation and Program Planning Vol. 31, 41-50

Manson C (2000). Schools with a future - A model for IT investment effectiveness. Paper presented at ACEC 2000 conference. Melbourne

Miller L, Naidoo M and van Belle J (2006). Critical success factors for ICT interventions in Western Cape schools. Proceedings of the $36^{\text {th }}$ SACLA Conference

Mishra P and Koehler MJ (2006).Technological Pedagogical Content Knowledge: A Framework for Teacher Knowledge Teachers College Record Vol. 108, No. 6, 1017-1054

Moseley D, Higgins S, Bramald R, Hardman F, Miller J, Mroz M, Tse H, Newton D, Thompson I, Williamson J, Halligan J, Bramald S, Tymms P, Henderson B, and Stout J (1999). Ways forward with ICT: Effective Pedagogy using Information and Communications Technology for Literacy and Numeracy in Primary Schools. http://www.leeds.ac.uk/educol/documents/00001369.htm

Myers M (1997). In Information Systems: An Emerging Discipline? London: McGraw-Hill

Neiss ML (2005). Preparing teachers to teach science and mathematics with technology: Developing a technology pedagogical content knowledge. Teaching and Teacher Education, 21(5), 509-523

Newhouse PC (2002). The impact of ICT on learning and teaching: a literature review for the Western Australian Department of Education. December

Robeyns I (2005). The Capability Approach: a theoretical survey. Journal of Human Development, Vol. 6 (1) 93-114

Rubin A and Babbie E (1989). Research Methods for Social Work. Belmont: Wadsworth Publishing Company

Sen AK (1984). Resources, Values and Development, Oxford: Basil Blackwell

Sen AK (1985). Well-being, Agency and Freedom: the Dewey Lectures. Journal of Philosophy, $82(4), 169.221$

Sen AK (1987). The Standard of Living: The Tanner Lectures, Cambridge: Cambridge University Press 
Sen AK (1992). Inequality Re-examined, Oxford: Clarendon Press

Sen AK (1993). Capability and Well-being. in Martha C. Nussbaum and Amartya K. Sen (eds), The Quality of Life, Oxford: Clarendon Press, pp. 30-53

Sen AK (1999). Development as Freedom, Oxford: Oxford University Press

Sen AK (2000). Social exclusion concept, application and scrutiny. Social Development Papers. No. 1, Asia Development Bank, Tokyo

Slaouti D and Barton A (2007). Opportunities for practice and development: newly qualified teachers and the use of information and communication technologies in teaching foreign languages in English secondary school contexts. Journal of In-service Education, 33(4), 19

Zheng Y and Walsham G (2008). Inequality of what? Social exclusion in the e-society as capability deprivation. Information Technology and People, Vol. 21(3), 222-243 